This item was submitted to Loughborough's Research Repository by the author.

Items in Figshare are protected by copyright, with all rights reserved, unless otherwise indicated.

\title{
Introduction: geographies, histories and practices of informal education
}

PLEASE CITE THE PUBLISHED VERSION

PUBLISHER

Palgrave Macmillan / @ The Authors reproduced with permission of Palgrave Macmillan

VERSION

AM (Accepted Manuscript)

\section{PUBLISHER STATEMENT}

This work is made available according to the conditions of the Creative Commons Attribution-NonCommercialNoDerivatives 4.0 International (CC BY-NC-ND 4.0) licence. Full details of this licence are available at: https://creativecommons.org/licenses/by-nc-nd/4.0/

\section{LICENCE}

CC BY-NC-ND 4.0

\section{REPOSITORY RECORD}

Mills, Sarah, and Peter Kraftl. 2019. "Introduction: Geographies, Histories and Practices of Informal Education". figshare. https://hdl.handle.net/2134/18040. 


\section{Introduction: Geographies, Histories and Practices of}

\section{Informal Education}

\section{Sarah Mills and Peter Kraftl}

In a 1943 survey of British youth work, Arthur Morgan described a range of youth clubs and organisations as ‘training place[s] in the social art of citizenship’ (p.102). Seventy years later, these types of voluntary and publicly funded spaces of non-formal or informal education 'beyond school' continue to occupy an important place in civil society as part of young people’s leisure activities, learning and wider socialisation. Simultaneously, these spaces are seen as addressing the needs of the state, used to mobilise wider political and policy-based discourses around participation, citizenship and engagement. For example, in 2013 the coalition government of the United Kingdom continues to roll out its National Citizen Service (NCS) scheme - 'for the lessons they can't teach you in class' - via a network of recently established charities and social businesses such as Catch22 that run alongside pilot programmes with long-standing youth organisations such as the Jewish Lads’ Brigade founded in 1895. In bringing together these varied youth partnerships, the very make-up of the NCS represents a kaleidoscope of informal education spaces in the United Kingdom and a sustained focus on ‘training places’ for children and young people.

The United Kingdom is not alone in its continued focus on young people’s citizenship education, moral fortitude and leisure activities that are part of much wider global historical trends (for example, Gagen, 2000, on these themes in early twentieth century New York; Alexander, 2009, on imperial Canada and India through the lens of Girl Guiding; and Verschelden et al., 2009 on the internationalisation of youth work practices across Europe). 
What then, are the wider landscapes of informal education across diverse geographical settings and international contexts? Indeed, the diversity of informal education relates to a whole series of everyday and spontaneous learning experiences that vary across different local, national and global contexts. And how have these spaces been understood, experienced and practised over time? It is these questions that frame this edited collection and its exploration of informal education, childhood and youth.

In beginning our editorial introduction with a point of connection between the past and present day, we illustrate one of the central aims of this book: to examine the geographies of informal education through both contemporary and historical examples. While a number of issues and popular understandings about children and young people have changed dramatically during the vast social, political and economic changes of the last few centuries, others remain strikingly similar, not least a series of powerful connections between youth and education. Childhood and youth are complex terms: socially constructed, historically contingent and variously located (Holloway and Valentine, 2000). Childhood continues to be used as a potent metaphor for hope (Kraftl, 2008), and ‘youth’ is constantly utilised as a mechanism for narrating wider global anxieties (Katz, 2008). In the context of debates surrounding informal education, there are a series of important relationships with childhood and youth: how are young people positioned within philosophies of informal education? In what ways do adult practitioners draw on notions of childhood? How do young people's identities shape their experiences of informal learning? And how have young people established and organised their own informal learning spaces? This edited collection brings together a range of studies that critically engage with these and other questions in a number of original contexts. Overall, the book examines a variety of learning spaces, practices and performances from diverse international settings and different historical epochs to explore, 
and in many cases push the boundaries of definitions and understandings of informal education. The primary aims of the edited book are four-fold:

$<$ list $>$

To examine the geographies of informal learning and why these matter.

To examine the histories of informal learning and why these matter.

To compile an engaging resource of case studies for critical reflection on practices of informal education for students, academics and practitioners.

To enhance our understandings of informal learning environments through informative and engaging examples that draw on recent theoretical developments in social and cultural geography and related disciplines. $</$ list $>$ In this brief editorial introduction, we define informal education and map out some key debates surrounding its meanings and use, before speaking about the subtitle of the book Geographies, Histories, Practices. Taking each in turn, we outline why geographies, histories and practices matter in the context of academic debates on informal education, expanding on the aims of the book while locating them in the relevant bodies of literature. Finally, we introduce the structure of the book and its chapters.

\section{Defining informal education}

Since the term refers to forms of learning that occur in and through everyday life, informal education can conceivably happen in an infinite array of situations, geographical and historical contexts. Understood thus, without wishing to recourse to essentialism, informal learning is an enduring and widespread facet of human experience (for an excellent resource containing many such examples, see www.infed.org). Yet, in particular times and places, informal learning has taken on rather more specific meanings. As Cartwright (2012) charts, 
informal education became a defined, deliberative and professionalised practice when philanthropic institutions such as the YMCA engaged in a variety of activities designed to support young people’s 'personal and social development' (Merton et al., 2004, p.5; cited in Cartwright, 2012, p.152). Informal education thus accompanied the rise of professionalised youth work, in particular in the United Kingdom after the Second World War. The relationships and tensions between youth work and informal education have been debated at length. Significant attention has been paid to the progressive professionalisation of youth work and its gendering (see Chapters 12 and 13 in this volume, respectively); by extension, critical discussion has centred around the colonisation of youth work by and for education policies that seek to manage the behaviour of 'at risk' youth and accord them responsibility for becoming self-governing, neoliberal subjects (for instance Jeffs, 2007; Davies and Merton, 2009). In all of these contexts, there is a perception that informal learning - and professional practices of informal education that seek to foster that learning - are being squeezed out.

Yet, these important debates notwithstanding, it is possible to identify at least three features of informal education that retain their significance in many contemporary contexts (after Cartwright, 2012). Firstly, informal learning is and should be a process that flows from the everyday concerns of young people (Falk et al., 2009). While an individual or group of young people may be identified as being somehow 'in need' of intervention, they should willingly engage in informal educational programmes and themselves identify the issues that should be addressed. Very often, therefore, space matters - informal education (ideally) takes place in locales where young people themselves choose to be and are most comfortable - be they youth clubs, street corners, bus stops or religious institutions. Indeed, it may be that those spaces themselves present the very everyday issues that foster further learning whether around bullying, sexual relationships, music, sports or something else entirely. 
However, informal learning need not necessarily take place in 'informal’ settings. Increasingly in the United Kingdom and other contexts, informal education takes place within mainstream schools (Jeffs, 2007) and, as several chapters in this volume show, within other institutional contexts such as scouting organisations, youth volunteering, alternative and nonformal education (see especially Part I and Chapter 11 by Dickens and Lonie).

Secondly, informal education relies heavily on dialogue and conversation. Informal education requires the building-up of trust, affinity, respect and even affection between educators and learners (Jeffs and Smith, 2005). Clearly, this is also a process that takes time. It requires a process of listening to young people’s everyday concerns and directing conversation (and related activities) in such a way that young people can reflect upon their own lives in a supportive environment (Young, 2006). Against charges that youth work in neoliberal contexts is being forced to become evermore instrumental, while simultaneously fire-fighting the 'problematic' or 'anti-social' behaviours displayed by young people, the dialogical nature of informal learning is meant to be non-teleological although not necessarily anti-teleological. That is to say, the outcomes of informal learning - which as Cartwright (2012) shows can be as diverse as a collective film or a change in a young person's emotional outlook - are not necessarily determined in advance, are contingent, but seek some kind of positive change.

Thirdly, informal education can involve some kind of (sometimes weakly) political edge. Informal educators may deliberately position themselves against the grain of apparent deficiencies of mainstream education, especially where their work is inspired by radical critiques of schooling (see Fielding and Moss, 2011; Kraftl, 2013). However, more commonly deriving influence from Paolo Freire (2008), informal education is conceived as a kind of learning from life, through dialogue, that enables a form of consciousness-raising (conscientização) among dispossessed groups to identify and seek means to overcome the 
social relations that dehumanise them. Thus, to take another key geographical term, informal education may inevitably involve a degree of upscaling, from the personal and the local through to issues of 'wider' socio-political concern. Key examples of this process of upscaling can be found in several chapters in this book, not least Sadlier's evocative analysis of the tarpaulin and the tablecloth as microspaces that are productive of 'politics of play, love and concern' in the public spaces of Oaxaca, Mexico.

In itself, the definition provided above is neither all-encompassing nor indicative of the many subtleties of informal education. The key aims of this text are, however, as indicated in the previous section, to both explore and push at the boundaries of the above definition in terms of the geographies, histories and practices that comprise informal education. It is our hope that the chapters in this text not only provide examples of the three features listed above in practice, but critically interrogate the role of informal education in a range of geographical and historical contexts, and through a range of theoretical perspectives. The next sections of this chapter provide some context as to our understanding of three key terms for this edited collection: geographies, histories and practices. While dealing with each in turn for the sake of clarity, we should stress that this volume brings together chapters that often interweave these three elements, as well as engaging with disciplinary debates in geography and history.

\section{Geographies of informal education}

In this volume, we use the term 'geographies' to refer to a range of perspectives on how informal educational practices operate in, through and as spaces. In some cases, the term refers to the particular geographical contexts in which informal education happens, and which are fundamental to our understanding of the situated nature of informal education. For instance, this volume includes chapters based in Mexico, the United Kingdom, Peru, Australia, Spain and the United States. In each country, informal education may flow from 
particular sets of social concerns, political currents and accepted ways of relating between (for instance) adults and young people.

It is, however, not sufficient to acknowledge that practices of informal education may vary across space as well as time, and to collate examples from around the world (indeed, this book is quite partial in terms of its geographical coverage). Rather, several of the chapters in this book seek to explore how practices of informal education are woven into and implicated in the complex social, political and cultural textures that make up particular places. This book is, then, based on an understanding of 'geography' that does not see educational processes as merely derivative of other, somehow more fundamental processes. Indeed, Hanson Thiem (2009) argues that for too long, geographical analyses of education have sought to emphasise how, for instance, school distribution is an outcome of this or that contemporary policy imperative, or how ethnic segregation in school catchments reflects wider social trends (cf. Bondi, 1991; Johnston et al., 2008). She contends that, despite their absolute significance, such approaches ‘neglect education’s constitutive properties - that is, how educational systems, institutions, and practices (and the political struggles that surround them) effect change beyond the sector' (Hanson Thiem, 2009, p.157, original emphasis).

In the above light, the ambition of a geographical approach to education is manifest not only in mapping the effects of political or economic currents at various spatial scales - as if geographical processes like distribution, segregation or migration were somehow separate from and a mere result of those currents. Rather, as Gulson and Symes (2007, p.3) point out, geographies of education require attentiveness to spatiality: to 'complex theorizations of material and symbolic life' where educational and spatial processes are indistinguishable from one another. Thus, Gulson and Symes build on decades of theorising about spatiality in disciplinary geography, wherein the term 
capture[s] the ways in which the social and spatial are inextricably realized in one another; [and] conjure[s] up the circumstances in which society and space are simultaneously realized by thinking, feeling, doing individuals and [...] the many different conditions in which such realizations are experienced. (Pile and Keith, 1993, p.6)

An acknowledgement of spatiality brings with it a requirement to exceed what immediately seems 'geographical' about education processes. Herein, the geographies of education (as both a scholarly endeavour and facets of the social world) may be conceived as complex, multifaceted and multi-scaled. In effect, from within disciplinary human geography alone, the geographies of education have increased and diversified enormously since the early 2000s. In a relatively early review, Collins and Coleman (2008) distinguished between studies that sought to examine the spaces within schools and those beyond school boundaries - a schematic that remains pertinent. On the former, a raft of studies has examined micro-scale interactions and power relations in dining halls (Pike, 2008), the design of school spaces and pupil participation therein (Kraftl, 2006; den Besten et al., 2011) and the classroom as a microcosm of larger imperatives for nation-building or citizenship education (e.g. Gruffudd, 1996; Pykett, 2012). On the latter, important research by geographers and others has critically examined the relationships between schools and their communities, and in particular the articulation of pedagogic linkages between home and school that may, frequently, be implicitly class-biased (see, in particular, Holloway and Pimlott-Wilson, 2011; Wainwright and Marandet, 2011). Here, there are clear parallels with the ways in which informal educators seek both to carve out spaces within formal/mainstream settings and to transcend boundaries between environments designated for learning and those apparently outside that design (Mills, 2013). In other words - as Cartwright (2012) has ably shown - an 
understanding of spaces within and beyond formally designated schools is arguably central for any analysis of informal education.

Geographical studies of education have also developed parallel to - and in conversation with - the so-called New Social Studies of Childhood (NSSC) (James and James, 2004; Jenks, 2005). Bridging sociology, anthropology, geography, education studies and a range of other disciplines, NSSC have been premised upon a commitment to interrogate the socially constituted elements of childhood experience and to foreground the agency, participation and voices of young people in both research and social life. It has been repeatedly shown that both the construction and experience of childhood are inherently spatial - from the rules that undergird intergenerational interactions in public spaces to the ways in which children seek to carve out niches in overwhelmingly adult-controlled environments (Holloway and Valentine, 2000; Matthews et al., 2000; for a review, see Kraftl et al., 2012). Although subject to a range of critiques (e.g. Prout, 2005; King, 2007; Philo, 2011), an understanding of children's experiences of education - as some of the many subjects of educational practices - has remained a significant component of research on education spaces (see Holloway et al., 2010, for an excellent review and examples). Critically, while focussing on the subjects of education, Holloway et al. argue that geographers themselves need to extend their repertoire of what 'count' as education spaces:

[W]e need to expand our interpretation of what count as spaces of education [... to] pay greater attention to the home, pre-school provision, neighbourhood spaces and afterschool care, as well as thinking more deeply about the ways in which people learn in subsistence agriculture, family businesses, paid work and so on. (Holloway et al., 2010, p.595) 
Resonating with some definitions of informal education (especially Falk et al., 2009), this statement can be reinterpreted as a call for greater interrogation of the spatialities of informal education, with a particular focus upon the teachers, practitioners, parents, young people and others who populate them. This is, in fact, a driving principle for the current volume. While not all of the chapters draw directly upon the experiences of young people, many do attend to the ways in which childhoods/youth are constructed through informal education spaces, and/or are based on empirical research with practitioners - who are clearly also key 'subjects' in education spaces (Holloway et al., 2010).

Of final and equal significance is a need to attune to the ways in which geographies of education may both draw on and inform key, contemporary conceptual debates. Two excellent edited collections are pertinent to the present volume, notable for their development of social-scientific understandings of embodiment and emotion. In one, Cook and Hemming (2011) curate a collection of papers on the multisensuous, embodied dynamics of education spaces - from the evocative sounds of a primary school corridor (Gallagher, 2011) to the disruptive aesthetic potential presented by the reorganisation of common design conventions in Higher Education classrooms (Lambert, 2011). In the second, Kenway and Youdell (2011) attend to some of the multiple intersections between emotion and educational spaces - from how 'emotional geographies are manifest in the formation and maintenance of particular racialisation and ethnicisation processes within a multicultural primary school' (Zembylas, 2011, p.151) to the production of feelings of alienation among young people excluded from mainstream school spaces (Nairn and Higgins, 2011). As we highlighted in the previous section, definitions of informal education highlight the importance of both interpersonal relationships and carefully managed situations, through which feelings such as trust, comfort and affection may emerge. Thus, many of the chapters in the present text also interrogate questions of emotion and embodiment, applying and developing these concepts through 
Scout and Guide camps, Care Farms, socio-emotional differences, music and information technologies. At the same time, many chapters develop a range of other theoretical perspectives, including feminist, radical and materialist perspectives on childhood, youth and pedagogy.

Geographies of education are becoming evermore diverse, arguably more disparate, and yet constitute an increasing presence across disciplinary human geography and beyond (Holloway and Jöns, 2012). This edited collection - which includes contributions from geographers and non-geographers - bears witness to some of that diversity. At the same time, it foregrounds the importance of geographical context, space, place and spatiality for understanding informal education. In particular, it demonstrates how informal education spaces are not merely derivative of, but may produce, inform, relate to and resist, contemporary socio-political processes.

\section{Histories of informal education}

In exploring the geographies of informal learning outlined above, this volume draws on both contemporary and, notably, historical examples. In doing so, this edited collection also contributes more broadly to histories of informal education. Significantly, this historical element is relatively new within the subdiscipline of children's geographies and geographies of education, discussed in the previous section. While there have been historical studies of formal schooling and children’s built environments within geography (Ploszajska, 1998; Gagen, 2000), the presence and activities of alternative and informal learning spaces over time have been hitherto neglected (although see Mills, 2013, on scouting and Cameron, 2006, on an experimental school). In excavating some of the hidden historical geographies of informal education, this text highlights the need to consider informal education over time as well as space. 
The history of informal education has also been a marginal but sustained interest for historians of childhood, leisure and youth (for example, Springhall, 1977; Proctor, 2002). Much of this scholarly focus - notably by informal educators and practitioners themselves has been on the history of youth work, often as part of wider studies on community work and voluntarism. Notably, a now well-established series of edited volumes based on conference proceedings has brought together histories of youth work, mainly focusing on nineteenth- and twentieth-century Britain (Gilchrist et al., 2001, 2003, 2006, 2009, 2011). There have also been more in-depth historical accounts of the institutional structures and wider social and political changes that have shaped youth work over time (Davies 1999a, 1999b), as well as studies charting the contribution of religious communities (for example Bunt, 1975, on Jewish youth work).

In more recent years, a much-needed wider lens has been cast over the history of youth work through a comparative European perspective. Three insightful edited volumes have sought to forge connections between the history of youth work in Europe with contemporary youth policy (Coussée et al., 2010, 2012; Verschelden et al., 2009). The volumes are both academically engaging and practical, with Coussée remarking in his own chapter that

[t]racing back the roots of youth work and identifying different evolutions within and between countries must help us to initiate a fundamental discussion on nowadays youth work identity and cope in a constructive way with the recurrent youth work paradoxes.

(Coussée, 2009, p.7)

In many ways, the policies and practices of youth work today are a legacy of the historical development of informal education, its related political motivations and the national (and international) policy contexts that have shaped its characteristics (see, for example, Smith and 
Doyle, 2002, on the impact of the Albemarle Report [1960] on youth work in England and Wales). However, for us, a focus on the histories of informal education extends beyond the social, political and economic factors that frame the historical development of youth work, to include multiple and enlivened histories of informal education that consider the fragmented, embodied and diverse experiences of informal learning across different spaces over time.

In opening up the histories of informal education to include but also go beyond youth work, this volume captures some of the past activities and influential legacies of educational thinkers (Donnachie, Chapter 6, on Robert Owen) as well as also offering a unique contribution on the gendered dimensions of post-war youth work and professional practice (Bradford, Chapter 12; Spence, Chapter 13). Furthermore, some authors explore the past philosophies and performances of different voluntary youth organisations (Kyle, Chapter 2; Mills Chapter 5). As Tony Jeffs notes:

[o]verwhelmingly, the historical material [relating to youth work] focuses on policy and agencies, and far too infrequently on what it meant to be a member or a 'client'. Few historians have moved beyond the study of youth work as an ongoing process to undertake the primary research required to understand how boys’ and girls’ clubs, uniformed groups, youth projects, and detached and outreach programmes worked in practice. (Jeffs, 2010, p.16, emphasis added)

This volume therefore highlights some potential conceptual and methodological entry points that begin to address Jeffs' call for what is clearly an important but much-larger project. For example, one potential avenue is to follow Kyle's unique approach in Chapter 2 of weaving contemporary and historical accounts of an informal learning space - the camp - together in one study. Overall, we contend that there is a pressing need to bring such enlivened histories into wider academic conversations about informal education, childhood and youth. The 
methodological innovations that have been utilised in diverse geographies of education, in particular within children’s geographies, could be further enhanced through historical approaches and source materials. Indeed, a number of historians of childhood, leisure and gender are engaging with diverse historical sources to gain insight into young people’s (past) experiences of spaces ‘beyond school’. For example, Tebbutt’s (2012) recent monograph uses a range of historical sources (including her own father's diaries) to explore the activities and practices of the Boys’ Brigade in Northampton, England, drawing on recent theorisations and writings in geography on mobility and place.

In terms of the present volume there is not one particular decade or historical period that authors focus upon; neither do we seek to claim a 'definitive history' of informal education (if indeed there can be such a thing) - but rather, the collection presents selected histories of informal education that are intimately entwined with the geographies of informal education. Indeed, the contributions do not simply chart developments or policies but rather push at some of the geographical sensibilities and spatialities (outlined in the previous section) either at a particular 'critical moment' in history, or over a longer period of time. Finally, it is also worth noting here that the book is structured thematically, rather than chronologically. This again highlights our (and the authors') commitment to exploring informal education, childhood and youth based on conceptual, thematic and analytical connections over time and space, rather than constructing a linear trajectory or particular national or regional focus. While seemingly disparate in terms of historical context, the chapters are united in their focus within structured parts (explored later in this introduction). Furthermore, authors make their own connections between historical and contemporaryfocused contributions. Taken together then, the chapters - while moving between different decades and indeed the present day - are complementary in their aim to explore the 
geographies of informal education and why these matter, as well as critically reflecting on the practices of informal education.

\section{Practices of informal education}

In addition to contributing to geographical and historical studies of informal education, there is something in the way that the contributors to this volume critically reflect on practice that is worthy of further attention and indeed comprises the third and final element of the volume’s subtitle. Here, and in the following chapters, practices are understood and addressed in three central ways, which resonate with the definition of informal education we provided above.

First, in terms of the people - practitioners, volunteers, educators, teachers or young people themselves - that literally 'do', ‘enable’ or 'facilitate' informal education. While education scholars and youth workers have acknowledged the need to critically reflect on professional practice and create space for 'voices of practice’ (Spence and Devanney, 2006; see also Richardson and Wolfe, 2001), this text extends this call through a number of contributions that reflect on the motivations, experiences and challenges for adult practitioners, as well as young people as educators themselves. In doing so, several authors reflect on how informal education is actually performed, rehearsed and experienced in practice (see Jeffs' quote in previous section).

Second, there is a focus within this text in most, if not all, chapters on the diverse material practices and technologies that enable informal education to take 'place' (see also Bekerman et al., 2005). At various points in the book, authors discuss young people’s embodied practices of camping, crafting, dancing, singing, mending, gardening, writing and blogging. Furthermore, a number of chapters highlight the role of material objects used by adults and young people to facilitate such activities and create a space for informal learning, for example firewood, tents or a computer. Elsewhere, in his study of alternative education in 
the United Kingdom, Kraftl has described the contingent and 'messy' practices of learning, arguing that 'alternative learning spaces are constantly characterised by an interplay between mess and order (or dis/order)' (Chapter 5 in this volume), and in some cases are understood through the absence of certain material objects associated with 'artefacts of school' (Chapter 5 in this volume). The authors in this volume attend to some of these materialities, highlighting how a range of technologies enable and negotiate experiences of informal education. This text therefore also contributes to some wider debates in social and cultural geography on childhood, materiality and embodiment.

Third, there is a need to focus on the everyday praxes - combinations of everyday pedagogic practice and political motivation - that drive informal education. Several of the chapters are situated within, or rub up against, both historical and contemporary political imperatives. They chart how some informal educators seek to make space for childhoods other than the flexible subjects by neoliberal regimes, while others wish to address inequalities in terms of gender or class. Commonly, the broader political goals of informal education are entwined with and produced by the everyday practices of dialogue and interpersonal interaction that we have identified above. In many ways, then, informal educators experiment with the hopeful, if not utopian, potentialities of everyday practice in order to raise the consciousness of young people so that - if only in a minor way - the seeds of social or political transformation may be sown (Cartwright, 2012; also Gardiner, 2004). Overall, informal education itself can be seen as an 'alternative practice', as Kraftl notes: 'there exist many alternative education practices that knowingly distance themselves from mainstream and especially state-sponsored schooling, whether or not they acknowledge that mainstream schooling can be massively diverse' (2012, p.2; also Woods and Woods, 2009). While the main focus of this book is not to interrogate the relationship between formal and informal learning, or critically evaluate the professional practices of informal educators, 
several chapters do address related themes in their examination of the geographies and histories of informal education. We now turn our focus to introducing these individual chapters, positioning them within the wider thematic structure of the book.

\section{The structure of the book}

Part I - ‘Nature Spaces’ - examines four separate organisations or informal learning spaces whose imaginative geographies draw upon nature, or whose 'alternative' learning activities occur outside, usually in rural environments. Historical and contemporary connections between youth, nature, morality and the 'great outdoors' are powerful (see, for example Philo, 1992; Matless, 1998). In Part I, the authors discuss several of these ideas, pushing conceptual understandings of 'inside/outside', while also making some broader arguments about the geographies and practices of informal education, specifically in a UK context. In Chapter 2, Richard Kyle draws on historical and contemporary data on the Boys' Brigade in Scotland to explore the 'extraordinary geographies' of camp. Using the joint metaphor of ‘cocoon' and 'chrysalis’ to explain how volunteers and the organisation have understood camp over time, he also argues that outdoor and indoor spaces of informal learning are 'locked in continual processes of co-creation'. Chapter 3, by Catherine Bannister, also interrogates the spaces and practices of camp, but this time in a contemporary sociological investigation of rituals and performances on Scout and Guide camps in England. By uniquely examining these two uniformed organisations together, Bannister argues that camp can be seen as a 'liminal' space where certain 'rites of passage' characterise these informal learning landscapes. Chapter 4, by Peter Kraftl, explores a small but growing number of Care Farms in the United Kingdom that operate, in part, as ‘alternative’ educational spaces to mainstream schools. Through interviews with Care Farm practitioners, Kraftl teases out the complex understandings of the 'local' within this community of informal educators. The varied types of local connectedness he discusses involve different relationships with the Care Farm's 
'constitutive outsides', or 'inside and outside the farm gate'. In Chapter 5, Sarah Mills echoes earlier arguments for a closer interrogation of outdoor and indoor spaces of informal education. In her study of the Woodcraft Folk between 1925 and 1975, Mills draws on archival material to consider the ways in which 'nature' (broadly conceived) was utilised not just 'on camp' but through a range of specific arts-based performances within indoor meeting places. In particular, she explores the role of music and dance as part of a wider examination of the pedagogical practices of this British youth movement.

Part II, ‘Negotiating In/formal Education Spaces’, explores some of the multiple sites within which informal education takes place. It highlights the connectedness of informal education within formal school spaces to informal education practices taking place without. In other words, informal education is often a mobile practice, which travels and may seek to transgress boundaries as much as constitute them, in multiple ways (see Collins and Coleman, 2008). In Chapter 6, Ian Donnachie examines the educational achievements of a social reformer whose work has influenced both formal and informal education practices: Robert Owen. With particular emphasis upon the relative microscale of the classrooms and playgrounds at New Lanark, Scotland, Donnachie nevertheless demonstrates how Owen’s ideas travelled well beyond Scotland, helping to stimulate educational reform both nationally and internationally. In Chapter 7, Stephen Sadlier focuses on Oaxaca City, Mexico, and the pedagogic projects of teachers in response to contemporary governance and rule in the country. He uses the tarpaulin and the tablecloth as both material case studies and metaphors for the extension of informal education beyond the school to small niches carved out in public space. In particular, these material-and-metaphorical spaces - these spatialities become sites for the expression of love, concern and empathy (cf. Freire, 2008). In Chapter 8, Dena Aufseeser focuses on the child workers’ movement in Peru. She explores the potential for informal education with children outside formal, mainstream institutions, and especially 
on the streets where they work. However, she places informal education in a symbiotic relationship with formal education: Peruvian children value formal schooling, but indicate that it is their street work that enables them to attend school and to acquire other, complementary, 'life’ skills. Chapter 9, by Sophie Bowlby, Jennifer Lea and Louise Holt, explores the attempts to intervene in, manage and regulate the 'socially unacceptable' behaviour of young people with socio-emotional differences. They examine how school teachers seek to 'teach' such young people how to make and keep friendships, to develop empathy and to socialise with other 'desirable' children. They argue in particular that the constitution of space-times, where predominant schooling norms are relaxed, may provide an opportunity for young people to develop the above kinds of emotional intelligence, but also reinforces a sense in which they are 'different' from other pupils. Chapter 10, by Kate Edwards, explores how current developments in e-learning may afford the potential for unsettling traditional conceptions of learning space. Drawing on research with school students, she demonstrates how, for instance, the presence of laptops affords a 'liberating' quality for students, which enables greater freedom in their interactions with other young people. She critically conceives of the 'third spaces' of e-learning, emphasising the importance of interaction and dialogue rather than the wholesale transferral of learning resources to online, bite-size repositories.

In Part III, 'Youth Work Spaces', the book turns to the long-standing relationship between youth work and informal education. In Chapter 11, Luke Dickens and Douglas Lonie explore music rehearsal spaces as catalysts for addressing the problems faced by young people living in disadvantaged neighbourhoods. They carefully seek to distinguish between non-formal and informal education, principally because the activities they describe involve a greater measure of planning and structure than most definitions of informal education allow. Drawing on the voices of young people, they articulate a disjuncture between the aims of the 
non-formal rehearsal spaces in which they worked (inclusion, regeneration) and a sense that for young people, the rehearsal spaces afforded an opportunity for informal, collaborative music-making that was unavailable elsewhere. In Chapter 12, Simon Bradford examines the professionalisation of youth work after the Second World War. He examines some of the embodied geographies of youth work, where young people's bodies (and their fitness) were conceived as a key medium for a rapidly developing profession. He also argues that the sequestration of particular leisure and public spaces as the 'proper places' of youth work was key, in particular because these were viewed as settings where young people's capacities to act responsibly could be developed. In Chapter 13, Jean Spence examines the period just after the 1960s, and focuses upon single-sex spaces of feminist youth work. Examining the period 1975-85, and through an analysis of contemporary newsletters, conference and research reports produced by feminist youth workers, she discusses how single-sex youth work spaces were viewed as critical to the girls' development. She highlights how a key principle of informal education - Freire's 'practice of freedom' - was deployed via activities that sought to raise girls’ consciousness about the gender inequalities that led to the marginalisation of women. In Chapter 14, Richard Davies explores some of the wider relationships between youth workers and school teachers through an analysis of the material arrangements of 'the school'. Through a philosophical approach drawing on his experience as a youth worker in schools in England, Davies argues that co-located working can disrupt the school, its borders and social geography.

Part IV, 'Youth-Led Spaces’, brings an explicit focus on spaces of informal learning organised, negotiated, and in some cases, established by young people themselves. Across a diverse set of geographical contexts (Australia, Spain and two US cities), the authors in this final part of the volume explore the ways in which youth-led schemes and projects are shaped and experienced by a range of young people, in particular through various technologies, 
materialities and public space. In Chapter 15, Shanene Ditton explores the different practices of a range of young people who seek to challenge the representations, cultural stigma and 'moral panic' surrounding Australia’s Gold Coast youth. She outlines processes of youth-led cultural change, drawing on Freire’s notion of ‘cultural voice’ (1970) and through an in-depth analysis of initiatives established by local young people, notably a zine and blog. In Chapter 16, Maria Rodó-de-Zárate and Mireia Baylina offer a rich account of the practices of a youthled feminist group in Barcelona. Using participatory methods, the authors focus on the girls' use of public space for various forms of social action and learning. In doing so, they highlight varied processes and practices of informal education, in particular around issues of selfmanagement, knowledge exchange and empowerment. In Chapter 17, Denise Goerisch focuses on a popular and well-established non-formal youth organisation in the United States - the Girl Scouts. Her study specifically explores the annual fundraiser of Girl Scout Cookie Sales, locating the scheme within wider neoliberal constructions of citizenship and debates surrounding financial literacy. Goerisch draws out the gendered ideologies espoused in the scheme, while importantly exploring how its leadership roles are understood and negotiated by young people themselves. In Chapter 18, Gregory T. Donovan explores young people’s consumption, production and governance of social and digital media. In particular, he interrogates shared understandings of privacy, property and security while also examining the varied learning practices surrounding the MyDigitalFootprint.ORG project, drawing on his participatory action design research with the Youth Design and Research Collective in New York City.

Overall, this volume brings together scholars from a range of diverse disciplinary backgrounds to consider the explicit, complex and diverse geographies of informal education. In our conclusion (Chapter 19), we reflect on the possible future directions of academic 
research on informal education that could be developed around recurring and important themes expressed in this collection.

\section{References}

K. Alexander (2009) 'The girl guide movement and imperial internationalism in interwar England, Canada and India', Journal of the History of Childhood and Youth, 2, 37-63.

Z. Bekerman, N. C. Burbules and D. Silberman-Keller (eds) (2005) Learning in Places: The informal education reader (New York: Peter Lang Publishing).

L. Bondi (1991) 'Attainment at primary schools: An analysis of variations between schools', British Educational Research Journal, 17, 203-17.

S. Bunt (1975) Jewish Youth Work: Past, present and future (London: Bedford Square Press).

L. Cameron (2006) 'Science, nature, and hatred: "finding out” at the Malting House Garden School, 1924-29’, Environment and Planning D: Society and space 24, 851-72.

I. Cartwright (2012) 'Informal education in compulsory schooling in the UK', in P. Kraftl, J. Horton and F. Tucker (eds) Critical Geographies of Childhood and Youth (Bristol: Policy Press).

D. Collins and T. Coleman (2008) 'Social geographies of education: Looking within, and beyond, school boundaries’, Geography Compass, 2, 281-99.

V. Cook and P. Hemming (2011) 'Education spaces: Embodied dimensions and dynamics', Social and Cultural Geography, 12, 1-8.

F. Coussée (2009) ‘The relevance of youth work’s history’ in G. Verschelden, F. Coussée, T. Van de Walle and H. Williamson (eds) The History of Youth Work in Europe - Relevance for Today’s Youth Work Policy - Volume 1 (Council of Europe publishing). 
F. Coussée, G. Verschelden, T. Van de Walle, M. Mędlińska and H. Williamson (2010) (eds) The History of Youth Work in Europe - Relevance for Today's Youth Work Policy - Volume 2 (Council of Europe Publishing).

F. Coussée, H. Williamson and G. Verschelden (eds) (2012) The History of Youth Work in Europe - Relevance for Today's Youth Work Policy - Volume 3 (Council of Europe publishing).

B. Davies (1999a) From Voluntaryism to Welfare State. A history of the youth service in England. Volume 1: 1939-1979 (Leicester: Youth Work Press).

B. Davies (1999b) From Thatcherism to New Labour. A history of the youth service in England. Volume 2: 1979-1999 (Leicester: Youth Work Press).

B. Davies and B. Merton (2009) Squaring the Circle? Findings of a 'modest inquiry' into the state of youth work practice in a changing policy environment (Leicester: De Montfort University).

O. den Besten, J. Horton, P. Adey, and P. Kraftl (2011) 'Claiming events of school (re)design: Materialising the promise of building schools for the future', Social and Cultural Geography, 12, 9-26.

J. Falk, J. Heimlich and S. Foutz (eds) (2009) Free-choice Learning and the Environment (Lanham, MD: AltaMira Press).

M. Fielding and P. Moss (2011) Radical Education and the Common School: A democratic alternative (London: Routledge).

P. Freire (2008) [1974] Education for Critical Consciousness (London: Continuum).

E. Gagen (2000) ‘An example to us all: Child development and identity construction in early 20th-century playgrounds', Environment and Planning A, 32, 599-616.

M. Gallagher (2011) 'Sound, space and power in a primary school’, Social and Cultural Geography, 12, 47-61. 
M. Gardiner (2004) ‘Everyday utopianism: Lefebvre and his critics’, Cultural Studies, 18, 228-54.

R. Gilchrist, T. Hodgson, T. Jeffs, J. Spence, N. Stanton and J. Walker (eds) (2011) Essays in the History of Youth and Community Work: Reflecting on the past (Lyme Regis: Russell House Publishing).

R. Gilchrist, T. Jeffs and J. Spence (eds) (2001) Essays in the History of Community and Youth Work (Leicester: National Youth Agency).

R. Gilchrist, T. Jeffs and J. Spence (eds) (2003) Architects of Change: Essays in the history of community and youth work (Leicester: National Youth Agency).

R. Gilchrist, T. Jeffs and J. Spence (eds) (2006) Drawing on the Past: Essays in the history of community and youth work (Leicester: National Youth Agency).

R. Gilchrist, T. Jeffs, J. Spence and J. Walker (eds) (2009) Essays in the History of Youth and Community Work: Discovering the past (Lyme Regis: Russell House Publishing).

P. Gruffudd (1996) ‘The countryside as educator: Schools, rurality and citizenship in interwar Wales’, Journal of Historical Geography, 22, 412-23.

K. Gulson and C. Symes (2007) Spatial theories of education: Policy and geography matters (London: Routledge).

C. Hanson Thiem (2009) 'Thinking through education: The geographies of contemporary educational restructuring', Progress in Human Geography, 33, 154-73.

S. Holloway, P. Hubbard, H. Jöns and H. Pimlott-Wilson (2010) 'Geographies of education and the significance of children, youth and families', Progress in Human Geography, 34, 583-600.

S. Holloway and H. Jöns (2012) ‘Geographies of education and learning’, Transactions of the Institute of British Geographers, 37, 482-88. 
S. Holloway and H. Pimlott-Wilson (2011) 'The politics of aspiration: Neo-liberal education policy, "low” parental aspirations and primary school Extended Services in disadvantaged communities', Children’s Geographies, 9, 79-94.

S. Holloway and G. Valentine (2000) 'Spatiality and the new social studies of childhood', Sociology, 34, 763-83.

A. James and A. James (2004) Constructing Childhood: Theory, policy and practice (Basingstoke: Palgrave Macmillan).

T. Jeffs (2007) 'Crossing the divide: School-based youth work’, in R. Harrison, C. Benjamin, S. Curran and R. Hunter (eds) Leading Work with Young People (Milton Keynes: OUP). T. Jeffs (2010) 'The relevance of history in youth work’ in F. Coussée, G. Verschelden, T. Van de Walle, M. Mędlińska and H. Williamson (eds) The History of Youth Work in Europe - Relevance for Today’s Youth Work Policy - Volume 2 (Council of Europe Publishing). T. Jeffs and M. Smith (2005) Informal Education: Conversation, democracy and learning (London: Educational Heretics Press).

C. Jenks (2005) Childhood (London: Routledge).

R. Johnston, S. Burgess, R. Harris and D. Wilson (2008) “ "Sleep-walking towards segregation'? The changing ethnic composition of English schools, 1997-2003: An entry cohort analysis', Transactions of the Institute of British Geographers, 33, 73-90.

C. Katz (2008) 'Childhood as spectacle: Relays of anxiety and the reconfiguration of the child’, Cultural Geographies, 15, 5-17.

J. Kenway and D. Youdell (2011) ‘The emotional geographies of education: Beginning a conversation', Emotion, Space and Society, 4, 131-6.

M. King (2007) 'The sociology of childhood as scientific communication: Observations from a social systems perspective', Childhood, 14, 192-213. 
P. Kraftl (2006) 'Building an idea: The material construction of an ideal childhood', Transactions of the Institute of British Geographers, 31, 488-504.

P. Kraftl (2008) 'Young people, hope and childhood-hope', Space and Culture, 11, 81-92.

P. Kraftl (2012) 'Towards geographies of “alternative” education: A case study of UK home schooling families, Transactions of the Institute of British Geographers, earlyview online DOI: 10.1111/j.1475-5661.2012.00536.x

P. Kraftl (2013) Geographies of Alternative Education: Diverse learning spaces for children and young people (Bristol: Policy Press).

P. Kraftl, J. Horton and F. Tucker (2012) Critical Geographies of Childhood and Youth: Contemporary policy and practice (Bristol: Policy Press).

C. Lambert (2011) 'Psycho classrooms: Teaching as a work of art', Social and Cultural Geography, 12, 27-46.

D. Matless (1998) Landscape and Englishness (London: Reaktion Books).

H. Matthews, M. Limb and M. Taylor (2000) The street as 'Thirdspace' in S. Holloway and G. Valentine (eds) Children's Geographies: Playing, living, learning (London: Routledge). S. Mills (2013) ““An instruction in good citizenship”: Scouting and the historical geographies of citizenship education', Transactions of the Institute of British Geographers, 38, 120-34.

A. E. Morgan (1943) Young Citizen (Harmondsworth: Penguin).

K. Nairn and J. Higgins (2011) 'The emotional geographies of neoliberal school reforms: Spaces of refuge and containment', Emotion, Space and Society, 4, 180-6.

C. Philo (1992) ‘Neglected rural geographies: A review’, Journal of Rural Studies, 8, 193207.

C. Philo (2011) ‘Foucault, sexuality and when not to listen to children’, Children’s Geographies, 9, 123-7. 
J. Pike (2008) ‘Foucault, space and primary school dining rooms’, Children’s Geographies, 6, 413-22.

S. Pile and M. Keith (1993) Place and the Politics of Identity (London: Routledge).

T. Ploszajska (1998) 'Down to earth? Geography fieldwork in English schools, 1870-1944', Environment and Planning D: Society and Space, 16, 757-774.

T. Proctor (2002) On My Honour: Guides and scouts in interwar Britain (Philadelphia: American Philosophical Society).

A. Prout (2005) The Future of Childhood (London: Routledge).

J. Pykett (2012) ‘Making “youth publics” and “neuro-citizens”: Critical geographies of contemporary education practice in the UK', in P. Kraftl, J. Horton and F. Tucker (eds) Critical Geographies of Childhood and Youth (Bristol: Policy Press).

L. D. Richardson and M. Wolfe (eds) (2001) Principles and Practice of Informal Education (London: Routledge).

J. Spence and C. A. Devanney (2006) Youth Work: Voices of practice (Leicester: National Youth Agency).

J. Springhall (1977) Youth, Empire and Society: British youth movements 1883-1940 (Beckenham: Croom Helm).

M. K. Smith and M. E. Doyle (2002) 'The Albemarle report and the development of youth work in England and Wales', The encyclopaedia of informal education, available at: http://www.infed.org/youthwork/albemarle_report.htm, date accessed 2 February 2013. M. Tebbutt (2012) Being Boys: Youth, leisure and identity in the inter-war years (Manchester: Manchester University Press).

G. Verschelden, F. Coussée, T. Van de Walle and H. Williamson (eds) (2009) The History of Youth Work in Europe - Relevance for Today's Youth Work Policy - Volume 1 (Council of Europe Publishing). 
E. Wainwright and E. Marandet (2011) 'Geographies of family learning and aspirations of belonging', Children's Geographies, 9, 95-110.

P. Woods and G. Woods (2009) Alternative Education for the 21st Century (London:

Palgrave).

K. Young (2006) The Art of Youth Work (Lyme Regis: Russell House).

M. Zembylas (2011) 'Investigating the emotional geographies of exclusion at a multicultural school', Emotion, Space and Society 4, 151-9. 